\title{
Strategies of coping with failure in the structure of managers' professional burnout syndrome
}

Professor Tatiana Ronginska,

University of Zielona Góra,

Poland,

ORCID: 0000-0002-3332-9262.

Artur Doliński, Ph.D., University of Zielona Góra,

Poland,

ORCID: 0000-0002-0656-6414.

\section{Introduction}

The professional burnout syndrome has continuously been the subject of interest of numerous researchers from the field of occupational and management psychology. Since the commencement of the research of this phenomenon (Freudenberger, 1974; Burisch, 1989; 2000; 2006; Maslach, 1982, 1986; Pines, Maslach, 1978) there has constantly apeeared the question about the determinants for the development of the syndrome and its substance, as it is a complex and multidimentional structure of inter-related symptoms. Profound analysis of the research data indicates that its leading symptom is increasing detrimental deformation of the emotional sphere of an individual: from enthusiasm at work bordering with euphoria to total resignation, apathy, passiveness, and desolation.

Characteristic features involved in the development of the syndrome are gradual changes in all mental spheres of a person: emotional, cognitive, motivational. Occurring in mutual relation, which allows for defining the syndrome as a structure of multiple elements covering the entirety of psychological 
properties of a person. The beginning of the syndrome's development is defined by Burisch as warning phase (Burisch, 1989), which signals exceedance of individual resources of a worker due to the fact that the primary feeling of great accomplishment is replaced with disappointment, irritation, negative emotions begin to prevail, helplessness and in consequence - apathy, and resignation from action(Lauderdale, 1982; Cherniss, 1980).The development of the burnout syndrome is of holistic nature, as all psychological spheres of a person are devastated. In the final stages, the feeling of alienation and existential void develop in a worker who, at the beginning, presented an ideal example of a person aspiring for the success at work.

A worker who is burnt out begins to present passive and defensive attitude, ceases action and withdraws from any cooperation. The latter appears among the professions requiring helping others, coordinating cooperation with colleagues, which aptly has been described by the metaphor "the syndrome of helpless helper" (Schmidbauer, 1997). Professional career of a person requires, among others, goal setting skills and formulation of strategies for effective realisation, which are immanently connected with the probability of occurence of mistakes as well as suffering failures. In our view, the crucial conditions for effective work of a human, therefore the predictors of mental health of a person in the working environment are the skills of rational overcoming obstacles and failures, being focused on finding and implementing new success achieving strategies. A person who is burnt out, by resigning from performing action negates the fact that failure may be one of the stages on the way to achieve goals, a stage which is carved into the process of professional development. Taking into account the argument above, and reflecting upon views of the other authors, the article attempts to verfy the hypothesis included in the title with regard to the research perspective of professional burnout syndrome.

\section{Method}

In order to validate the theory of the decisive role of the coping with failure skill, in the research a Polish version of (Rongińska, Gaida, 2012) questionnaire "Wzorzec Zachowań i Przeżyć związanych z pracą - AVEM" (Arbeitsbezogenes Verhaltens- und Erlebensmuster - AVEM, Schaarschmidt\&Fischer, 1997) is applied. In the process of developing the tool, a number of authors' views on the substance of the phenomenon of burnout were taken into account. Among most notable symptoms one can outline: 
- resignation and resentiment (Bäurle, 1969),

- mental exhaustion in the form of the loss of positive attitude towards work, depersonalisation (Pines, Maslach, 1978),

- feeling of solitude (Freudenberger,1992),

- resignation from action, feeling of helplessness (Freudenberger (1974),

- engagement reduction (Burisch, 1994),

- reduction of mechanisms of conflict solving to denial and blocking (Freudenberger, North, 1992).

The construction of the questionnaire allows for the analysis of the structure of the professional burnout syndrome by utilising 11 systems of measurement containing human's behavioural spheres concerning individual level of engagement in work, emotional attitude towards work, and resilience against stress and frustrating situations. These are: Subjective meaning of work(BA); Professional ambitions (BE); Readiness for energy expenditure - involvement (VB); Aspitation for perfection (PS); Ability to distance oneself (DF); Tendency to resignation in case of failure (RT); Offensive strategy of solving problems (OB); Inner peace and balance (IR); Sense of success at work (EB); Satisfaction from life(LZ); Sense of social support (SU). The constellation of values of each scale, ie. type B (Burnout), which is characterised by: high tendency to fast resignation in the situation of failure, extremely low level of engagement in performing professional tasks, taking defensive attitude in the situations of growing problems, and negative attitude towards self and the others. In other words, a person who is burnt out quickly steps aside in the situation of failure, resigns from making further attempts to find alternative forms of behaviour.

AVEM questionnaire has undergone psychometric adaptation procedure to fit Polish conditions. High accuracy coefficients have been reached by using the method of split-half $r_{12}$ (acc. Spearman-Brown) and internal compliance $a$ (acc. Cronbach) for particular scales: Subjective meaning of work $\left(\mathrm{r}_{12}=0.79 ; \mathrm{a}=0.81\right)$; Professional ambitions $\left(\mathrm{r}_{12}=0.72 ; \mathrm{a}=0.72\right)$; Readiness for energy expenditure involvement $\left(r_{12}=0.70 ; a=0.71\right)$; Aspiration for perfection $\left(r_{12}=0.69 ; a=0.73\right)$; Ability to distance oneself $\left(\mathrm{r}_{12}=0.82 ; \alpha=0.82\right)$; Tendency to resignation in case of failure $\left(\mathrm{r}_{12}=0.70 ; \mathrm{a}=0.72\right)$; Offensive strategy of solving problems $\left(\mathrm{r}_{12}=0.70 ; \mathrm{a}=\right.$ $0.74)$; Inner peace and balance $\left(\mathrm{r}_{12}=0.78\right.$; $\left.\alpha=0.75\right)$; Sense of success at work $\left(\mathrm{r}_{12}\right.$ $=0.83$; $\alpha=0.84)$; Satisfaction from life $\left(r_{12}=0.76 ; \alpha=0.78\right)$; Sense of social support $\left(\mathrm{r}_{12}=0.73 ; \mathrm{a}=0.73\right)$ (Rongińska, Gajda 2012).

Current research on professional burnout vividly indicate the existence of key predictors conditioning the development of syndrome's symptoms (Ronginska, 2001; 2002, 2010; 2011). The empirical material presented in this article is the 
continuation of the research of the matter in order to further explain the key elements of the structure of the professional burnout syndrome .

Research goals and research hypothesis:

- analysis of the intensity of the professional burnout syndrome symptoms creating the type B behavioural model depending on subjects' gender,

- pursuit for the answer to the question whether there is a common factor determining the occurence of professional burnout syndrome measured by AVEM questionnaire among women and men working in management positions.

Research hypothesis. The determining factor for the intensity of porfessional burnout syndrome symptoms among the group of managers of both genders is the lack of skill in coping with failure with prevalence of the defensive strategy for solving problems.

\section{Characteristics of the test group}

Mid-level managers of both genders employed in state-run companies were the subjects of the research $(\mathrm{N}=2164)$. It has been assumed that mid-level managers effectuate a series of operational actions in the companies. They are subjected to the influence of top-level managers (deciding about i.e. direction of actions, strategies, working standards) and regular employees (who glorify or contest the decisions of top managers). One can assume that the mid-level managers are exposed to experiencing failures due to emerging discrepancy between the expectations of their superiors and the expectations of regular employees as their role is to implement and directly supervise actions. From the group, 198 people (103 women and 95 men) with high-probability $(\mathrm{p}=0.85)$ and qualified for the behavioural model B (Burnout) have been subjected to further analysis.

\section{Research outcomes}

The research outcomes were presented by, initially, the analysis of the averages of respective scales. Next, the dispersion of scale results for women and men was assesed by the utilisation of variability coefficient. The following stage was to indicate the key predictors of the burnout by means of regression analysis.

The first step, an attempt was made to analyse the variability coefficients for AVEM scales. The variability coefficient allows for setting preliminary measure of differentiation of a given feature. The matter of our interest was in which AVEM scale the results are the most similar to each other. In the case of low

97

TATIANA RONGINSKA

ARTUR DOLIŃSKI 
variability of the analysed feature (here regarding the questionnaire of AVEM scale), it is assumed that the scale has the key significance in the formation of the burnout syndrome. Table 1 presents the averages, standard deviations, and variability coefficients for particular scales creating the AVEM profile in the group of burnt-out women.

Table 1. Averages, standard deviations and variability coefficients for particular scales creating the AVEM profile in the group of burnt-out women

\begin{tabular}{|c|c|c|c|c|}
\hline Scales AVEM & $\begin{array}{c}M \\
\text { Women } \\
(n=103)\end{array}$ & D & $\mathbf{v}$ & Interpretation \\
\hline Subjective meaning of work (BA) & 14.5728 & 3.68 & 25.26 & Average variability \\
\hline Professional ambitions (BE) & 18.0583 & 3.88 & 21.50 & Average variability \\
\hline $\begin{array}{l}\text { Readiness for energy expenditure - } \\
\text { involvement (VB) }\end{array}$ & 19.8641 & 3.66 & 18.43 & Low variability \\
\hline Aspiration for perfection(PS) & 21.9612 & 2.65 & 12.08 & Low variability \\
\hline Ability to distance oneself (DF) & 17.4078 & 2.68 & 15.44 & Low variability \\
\hline Tendency to resignation in case of failure (RT) & 19.7767 & 2.45 & 12.42 & Low variability \\
\hline Offensive strategy of solving problems (OP) & 17.5243 & 3.12 & 17.82 & Low variability \\
\hline Inner peace and balance (IR) & 15.6019 & 4.18 & 26.81 & Average variability \\
\hline Sense of success at work(EB) & 16.8738 & 3.82 & 22.64 & Average variability \\
\hline Satisfaction from life(LZ) & 16.8058 & 3.76 & 22.38 & Average variability \\
\hline Sense of social support (SU) & 19.4369 & 4.44 & 22.86 & Average variability \\
\hline
\end{tabular}

Legend: M - average; D - standard deviation; $\mathrm{v}$ - variability coefficient

Source: own study

In the group of women qualified for high probability for burnout (type B) the lowest variability coefficient values refer to scales:

- aspiration for perfection $(v=12.08)$,

- ability to distance oneself $(v=15.44)$,

- tendency to resignation in case of failure $(v=12.42)$,

- offensive strategy of solving problems $(v=17.82)$. 
The closest results in the group of women were achieved in scales "Aspiration for perfection" and "Tendency to resignation in case of failure" ( $v=12.08$; $\mathrm{v}=12.42$ ), which indicates the leading role of those paradigms in the formation of professional burnout syndrome symptoms.

Table 2 presents the averages, standard deviations, and variability coefficients for particular scales creating the AVEM profile in the group of burnt-out men.

Table 2. Averages, standard deviations and variability coefficients for particular scales creating the AVEM profile in the group of burnt-out women

\begin{tabular}{l|c|c|c|l}
\hline \multicolumn{1}{c|}{ Scales AVEM } & $\begin{array}{c}\text { M } \\
\text { Men (n=95) }\end{array}$ & D & V & \multicolumn{1}{c}{ Interpretation } \\
\hline Subjective meaning of work (BA) & 14.9684 & 5.23 & 34.99 & Average variability \\
\hline Professional ambitions (BE) & 17.6737 & 3.70 & 20.96 & Average variability \\
\hline $\begin{array}{l}\text { Readiness for energy expenditure } \\
\text { involvement (VB) }\end{array}$ & 18.3895 & 3.98 & 21.66 & Average variability \\
\hline Aspiration for perfection( (PS) & 19.5474 & 2.63 & 13.48 & Low variability \\
\hline Ability to distance oneself (DF) & 18.2842 & 2.84 & 15.56 & Low variability \\
\hline $\begin{array}{l}\text { Tendency to resignation in case of failure } \\
\text { (RT) }\end{array}$ & 18.4000 & 2.35 & 12.78 & Low variability \\
\hline Offensive strategy of solving problems (OP) & 17.7789 & 3.01 & 16.93 & Low variability \\
\hline Inner peace and balance (IR) & 16.7684 & 4.24 & 25.29 & Average variability \\
\hline Sense of success at work (EB) & 16.0526 & 3.68 & 22.94 & Average variability \\
\hline Satisfaction from life (LZ) & 16.0947 & 3.51 & 21.80 & Average variability \\
\hline Sense of social support (SU) & 17.8316 & 3.97 & 22.27 & Average variability \\
\hline
\end{tabular}

Legend: $\mathrm{M}$ - average, D - standard deviation, $\mathrm{v}$ - variability coefficient

\section{Source: own study}

Among burnt-out men the lowest standard deviation and variability coefficient values refer to scales:

- ability to distance oneself ( $v=15.56)$,

- tendency to resignation in case of failure $(\mathrm{v}=12.78)$,

- offensive strategy of solving problems ( $v=16.93)$. 
The closest results in the group of women were achieved in scales "Aspiration for perfection" and "Tendency to resignation in case of failure" ( $v=13.48$; $\mathrm{v}=12.78$ ), which indicates the leading role of those paradigms in the formation of professional burnout syndrome symptoms.

In order to confirm the assumption regarding the role of resignation factors in the situation of failure with prevalence of the defensive strategy for solving problems, the linear regression analysis was performed by using the method of application.

Table 3. Results of the linear regression analysis by method of application in the group of women

\begin{tabular}{|c|c|c|c|c|c|}
\hline \multirow{2}{*}{ Model } & \multicolumn{2}{|c|}{$\begin{array}{l}\text { Non-standardised } \\
\text { coefficients }\end{array}$} & \multirow{2}{*}{$\begin{array}{c}\begin{array}{c}\text { Standardised } \\
\text { coefficients }\end{array} \\
\text { Beta }\end{array}$} & \multirow{2}{*}{$\mathbf{t}$} & \multirow{2}{*}{$\begin{array}{l}\text { Signifi- } \\
\text { cance }\end{array}$} \\
\hline & B & $\begin{array}{l}\text { Standard } \\
\text { error }\end{array}$ & & & \\
\hline (Constant) & 2.148 & .129 & & 16.594 & .000 \\
\hline BA Subjective meaning of work & -.010 & .002 & -.153 & -4.389 & .000 \\
\hline BE Professional ambitions & -.012 & .003 & -.152 & -4.318 & .000 \\
\hline $\begin{array}{l}\text { VB Readiness for energy } \\
\text { expenditure - einvolvement }\end{array}$ & -.009 & .003 & -.127 & -3.354 & .001 \\
\hline DF Ability to distance oneself & -.011 & .002 & -.152 & -4.416 & .000 \\
\hline $\begin{array}{l}\text { RT Tendency to resignation in } \\
\text { case of failure }\end{array}$ & .015 & .003 & .199 & 5.734 & .000 \\
\hline $\begin{array}{l}\text { OP Offensive strategy of solving } \\
\text { problems }\end{array}$ & -.011 & .003 & -.134 & -3.592 & .000 \\
\hline IR Inner peace and balance & -.014 & .002 & -.169 & -5.505 & .000 \\
\hline EB Sense of success at work & -.014 & .003 & -.177 & -5.084 & .000 \\
\hline LZ Satisfaction from life & -.021 & .003 & -.263 & -6.837 & .000 \\
\hline SU Sense of social support & -.006 & .002 & -.079 & -2.402 & .017 \\
\hline
\end{tabular}

a. Gender $=\mathrm{K}$

$R$ - square $=0.674$; explanation of the percent of dependent variable variance by predictors attached to the model

Source: own study 
Conclusion: Aspiration for perfection scale has not entered the model.

The highest impact on belonging to burnout type B have: Satisfaction from life (correlation); and Tendency to resignation in case of failure.

Table 4. Results of the linear regression analysis by method of application in the group of men

\begin{tabular}{|c|c|c|c|c|c|}
\hline \multirow{2}{*}{ Model } & \multicolumn{2}{|c|}{$\begin{array}{l}\text { Non-standardised } \\
\text { coefficients }\end{array}$} & \multirow{2}{*}{$\begin{array}{c}\text { Standardised } \\
\text { coefficients } \\
\text { Beta }\end{array}$} & \multirow{2}{*}{$\mathbf{t}$} & \multirow{2}{*}{ Significance } \\
\hline & B & $\begin{array}{l}\text { Standard } \\
\text { error }\end{array}$ & & & \\
\hline (Constant) & 1.742 & .149 & & 11.714 & .000 \\
\hline BA Subjective meaning of work & -.013 & .003 & -.206 & -4.712 & .000 \\
\hline DF Ability to distance oneself & -.012 & .003 & -.207 & -4.221 & .000 \\
\hline $\begin{array}{l}\text { RT Tendency to resignation in } \\
\text { case of failure }\end{array}$ & .012 & .003 & .178 & 3.604 & .000 \\
\hline $\begin{array}{l}\text { OP Offensive strategy of solving } \\
\text { problems }\end{array}$ & -.022 & .004 & -.294 & -5.470 & .000 \\
\hline IR Inner peace and balance & -.015 & .003 & -.209 & -4.996 & .000 \\
\hline EB Sense of success at work & -.010 & .003 & -.129 & -2.943 & .004 \\
\hline LZ Satisfaction from life & -.014 & .004 & -.185 & -3.570 & .000 \\
\hline
\end{tabular}

a. Gender $=\mathrm{M}$

$R$ - square $=0.674$; explanation of the percent of dependent variable variance by predictors attached to the model

Source: own study

Conclusion: professional ambitions, engagement in profession, aspiration for perfection and sense of social support have not entered the model.

The highest impact on belonging to burnout type $\mathbf{B}$ has offensive problem solving strategy. 


\section{Research conclusions}

On the basis of the analysis one can state as follows: The factor determining the higher intensity of symptoms of professional burnout among groups of women and men working in management positions is the lack of coping with failure skills with prevalence of defensive strategy of solving problems, which results in the decrease in Satisfaction from life with regard to professional life.

In order to construct the strategy of early prevention of development of the professional burnout syndrome's symptoms one can suggest the following undertakings:

- releasing additional prevention resources in the situations of failure to counteract resignation (coaching etc.),

- enforcing the offensive style of solving problems as an active and positive attitude towards challenges and professional requirements,

- enforcement of celebrating success at work - concentration on positive achievements as prevention of decreasing of the satisfaction from own actions.

\section{Summary and practical implications}

The research regarding the group of managers allows for acceptance of the thesis that in the structure of aspects of burnout syndrome described in this article, the leading symptom is the increased tendency to resign in the situations of failure as well as adopting defensive strategy of coping with difficult situations. The specifics of the burnout phenomenon results from the vitiation of the optimal strategies with coping with high level of stress at work, for the way of dealing with the situation by resigning does not seem to be an effective solution, what is more, it deepens the problems at work by accumulating dissatisfaction, irritation and total withdrawal of motivation. Preventive measures for the group of managers are expected to be concentrated on enforcing the confidence in self-effectiveness and also detecting additional support resources in the situations of failure in order to avoid the creation of feelings such as alienation and senselessness in the work environment. Developing the belief in self effectiveness releases additional individual resources and, in turn, leads to the increase of team work quality and support in overcoming the individualism crisis, enforcement of the group support, creation of conditions for "healthy life field" as opposed to "life field burdened by the health risk" (Sęk, 1987).

Strategies of coping with failure in the structure of managers ' professional burnout syndrome 


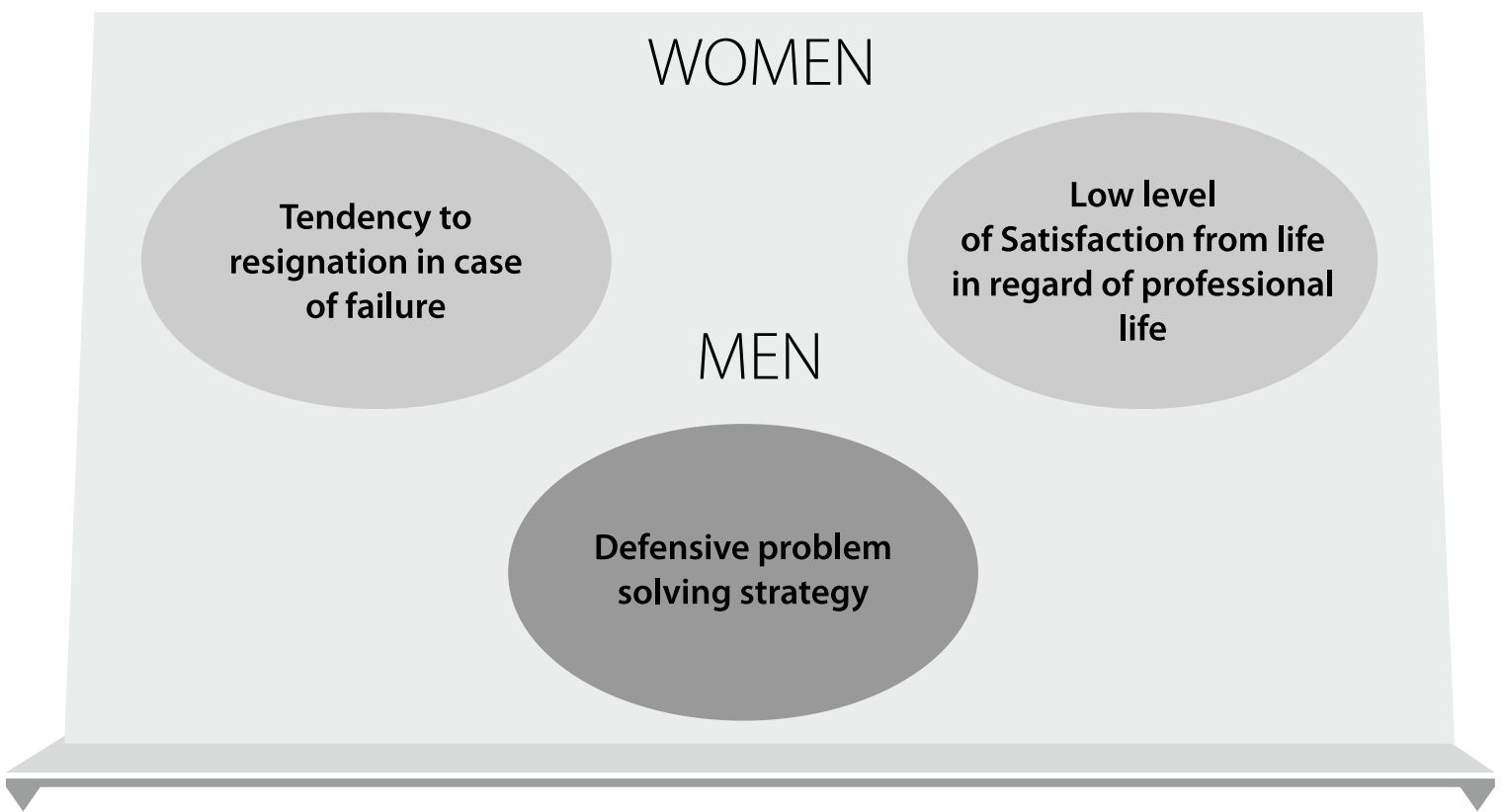

Figure 1. Deficits of individual resources in the group of burnt-out women and man in management positions

Source: own study

In the summary, the main guidelines for the creation of prevention programmes are shown. They present which deficits in the group of individual resources shall be enforcced by introducing a variety of training forms, such as workshops or coaching sessions to the group of women and men managements.

\section{Summary}

Strategies of coping with failure in the structure of managers ${ }^{\prime}$ professional burnout syndrome

The report presents the results of research on predictors of professional burnout syndrome among women and men working in management positions. The research included over 2000 people working in a variety of workplaces. For the analysis of content and structure of burnout syndrome, 198 people with high probability for occurence of the burnout symptoms were qualified. In the study, a Polish version of Questionnaire of Behaviour and Experiences connected with AVEM (Arbeitsbezogenes Verhaltensund Erlebensmuster, Schaarschmidt, Fischer, 1997) were used. 
With the help of regression analysis, the key components of syndrome's structure were determined, with pointing to the leading significance of coping with failure and defensive attitude in enforcing its symptoms. Suggestions for prevention measures against the burnout syndrome which are concentrated on strenghtening the skill of coping with failure have been presented.

Keywords: professional burnout syndrome, resignation, coping with failure, offensive strategy.

JEL

Classification: M 120

\section{Streszczenie}

Strategie radzenia sobie $\mathrm{z}$ porażką $\mathrm{w}$ strukturze syndromu wypalenia zawodowego menedżerów

W artykule przedstawiono wyniki badań predyktorów syndromu wypalenia zawodowego w grupie kobiet i mężczyzn na stanowiskach kierowniczych. $W$ badaniach uczestniczyło ponad 2000 osób pracujących w różnych zakładach pracy. Do analizy treści i struktury syndromu wypalenia zakwalifikowano 198 osób z wysokim prawdopodobieństwem wystąpienia objaww wypalenia. $\mathrm{W}$ badaniach zastosowano polską wersję Kwestionariusza Zachowań i Przeżyć związanych z pracą AVEM (Arbeitsbezogenes Verhaltens- und Erlebensmuster, Schaarschmidt, Fischer, 1997). Przy pomocy analizy regresji ustalono kluczowe składniki struktury syndromu ze wskazaniem na wiodące znaczenie braku umiejętności radzenia sobie z porażką i przyjęcie postawy defensywnej w nasileniu jego objawów. Przedstawiono możliwości profilaktyki syndromu wypalenia zawodowego skoncentrowanej na wzmocnieniu umiejętności radzenia sobie z porażką.

\section{Słowa}

kluczowe: syndrom wypalenia zawodowego, rezygnacja, radzenie sobie z porażka, ofensywna strategia. 


\section{References}

Bäuerle, D. Supervison in der Sozialpädagogik und Sozialarbeit. Neues Beginnen. 1969; $21 \mathrm{ff}$.

Burisch, M. (1989). Das Burnout-Syndrom - Theorie der inneren Erschöpfung. 2. Auflage. Berlin- Heidelberg: Springer.

Burisch, M. (2000). W poszukiwaniu teorii - przemyślenia na temat natury i etiologii wypalenia. In: Sęk, H. (ed.). Wypalenie zawodowe. Przyczyny. Mechanizmy. Zapobieganie. Warszawa, PWN, pp. 58-82.

Burisch, M. (2006). Das Burnout-Syndrom - Theorie der inneren Erschöpfung. 3. Auflage. Berlin- Heidelberg: Springer.

Cherniss C. (1980). Professional Burnout in Human Service Organizations, New York: Praeger.

Freudenberger, H., North, G. (1992). Burn-out bei Frauen. Über das Gefühl des Ausgebranntseins. Frankfurt a.M.: Krüger.

Lauderdale M. (1982). Burnout. Austin, TX: Learning Concepts.

Maslach, C., Jackson, S. E. (1986). Maslach Burnout Inventory (MBI). Manual. Palo Alto: Consulting Psychologists Press.

Pines, A., Maslach, C. (1978). Characteristics of staff burnout in mental health settings. Hospital \& Community Psychiatry, 29(4), 233-237.

Maslach, Ch. (1982). Understanding burnout: Definitional issues in analyzing a complex phenomenon. Paine, W.S. Job, Stress and Burnout. Beverly Hills: Sage, pp. 26-31.

Rongińska, T. (2001). Źródła i przejawy wypalenia psychicznego w zawodzie nauczycielskim. Pomiar edukacyjny jako kompetencje pedagogiczne. Materiały konferencji naukowej. Diagnostyka edukacyjna jako dziedzina kompetencji pedagogicznych. Szczecin, pp. 165-173.

Rongińska, T. (2002). Wczesna profilaktyka wypalenia zawodowego wśród przysztych nauczycieli. Osoba - edukacja - dialog. (ed.) M. Ledzińska, G. Rudkowska, L. Wrona, Vol. 2, Kraków, Wydaw. Naukowe Akademii Pedagogicznej, pp.82-91.

Rongińska, T. (2010). Profilaktyka syndromu wypalenia zawodowego funkcjonariuszy stużby więziennej. Prolegomena bezpieczeństwa publicznego (ed.) T. Zaborowski. Zielona Góra: Zachodnia Wyższa Szkoła Handlu i Finansów Międzynarodowych im. Jana Pawła II, s. 57-60.

Rongińska, T. (2011). The prevention of the managers' professional burnout syndrome. Management Vol. 15, No. 1, pp. 101-114.

Rongińska, T., Gaida, W. (2012). Strategie radzenia sobie z obciażeniem psychicznym w pracy zawodowej. Polska adaptacja kwestionariusza, Wzorzec zachowań i przeżyć związanych z pracą (Arbeitsbezogenes Verhaltensund Erlebensmuster - AVEM) U. Schaarschmidt'a i A. Fischer'a, Zielona Góra. Zielona Góra, Oficyna wyd. UZ. 
Sęk H. (1987). Psychological concepts of health, modes of prevention and counselling for health promotion, Polish Psychological Bulletin, 18, 77.

Schaarschmidt, U. \& Fischer, A. W. (1997). AVEM - ein diagnostisches Instrument zur Differenzierung von Typen gesundheitsrelevanten Verhaltens und Erlebens gegenüber der Arbeit. Zeitschrift für Differentielle und Diagnostische Psychologie, 18, Heft 3, 151-163.

Schmidbauer, W. (1997). Die hilflosen Helfer. Über die seelische Problematik helfender Berufe. Reinbek: Rowohlt. 